\title{
Possibility of Using Fuel Cells for Co-generation of Heat and Power in Venizelio Hospital in Crete, Greece
}

\author{
John Vourdoubas \\ Consultant Engineer, 107B El. Venizelou str., 73132, Chania, Crete, Greece
}

E-mail: ivourdoubas@gmail.com

Received: November 13, $2021 \quad$ Accepted: December 30, $2021 \quad$ Published: X, 2021

doi:10.5296/emsd.v11i1.19191～URL: https://doi.org/10.5296/emsd.v11i1.19191

\begin{abstract}
Mitigation of climate change requires the replacement of traditional energy technologies with novel low carbon energy systems. The possibility of using a fuel cell and a hybrid energy system consisted of a fuel cell and solar-PV panel for energy generation in Venizelio hospital located in Crete, Greece has been investigated. The size, the heat and electricity generated, the $\mathrm{H}_{2}$ required and the capital cost of the fuel cell and the solar-PV system covering the energy requirements in the hospital have been estimated. Existing research has indicated that fuel cells using $\mathrm{H}_{2}$ can cover the heat and electricity needs in various buildings. Our results indicated that a fuel cell at $1397 \mathrm{KW}$ can produce annually $4895 \mathrm{MWh}_{\mathrm{el}}$ and $4895 \mathrm{MWh}_{\mathrm{th}}$ covering all the electricity and heating needs in Venizelio hospital producing excess heat at 2 $451 \mathrm{MWh}_{\text {th }}$. The capital cost of the fuel cell has been calculated at $4191000 €$ while the required $\mathrm{H}_{2}$ at 367.5 tons/year. All the energy requirements of the hospital can be also covered with a hybrid energy system consisted of a fuel cell and a solar-PV system. The size of the fuel cell has been estimated at $697.5 \mathrm{KW}$ and the cost at $2092500 €$. The electricity generation was at $2444 \mathrm{KWh}_{\mathrm{el}}$ and its heat production at $2444 \mathrm{KWh}_{\mathrm{th}}$. The size of the solar-PV system has been evaluated at $1629 \mathrm{KW}_{\mathrm{p}}$ and the cost at $1634000 €$. The annual electricity generation was at $2451 \mathrm{MWh}_{\mathrm{el}}$. The capital cost of the hybrid energy system at 3 $726500 €$ is lower than the cost of the fuel cell alone at $4191000 €$. Our results indicated that the use of novel benign energy systems with zero carbon emissions in Venizelio hospital is technically and economically feasible.
\end{abstract}

Keywords: Crete-Greece, Electricity, Fuel cells, Heat, Hospital, Hydrogen, Solar-PV

\section{Introduction}

Climate change is the most important environmental problem threatening the prosperity of developing and developed societies. Its mitigation is of paramount importance while Europe as well as other countries aim to achieve net zero carbon societies in the coming decades. 


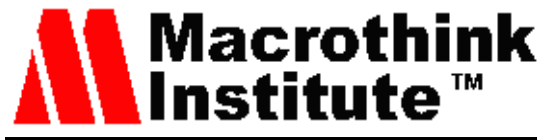

This can be obtained with the use of clean energy sources and technologies, instead of fossil fuels, zeroing the net $\mathrm{CO}_{2}$ emissions into the atmosphere. Hospitals utilize large amounts of energy operating continuously all over the year while their buildings have the highest specific energy consumption among other types of buildings. They mainly utilize fossil fuels while the use of renewable energies in covering their energy needs is so far limited. Current advances in benign energy technologies allow their use in various sectors replacing fossil fuels and minimizing carbon emissions due to energy use. Use of low carbon emissions sources and technologies in hospitals will promote their environmental sustainability. Combined use of various renewable energy technologies and hybrid energy systems can minimize the use of fossil fuels and their atmospheric carbon emissions contributing to the global target for net zero carbon societies. Fuel cells are energy efficient heat and power co-generation systems while their use in many sectors is growing. Solar-PV systems are broadly used to day in electricity generation since their cost has significantly decreased and their use is profitable. Our research is important since it indicates that modern sustainable energy technologies can be used in hospitals covering their energy requirements in a cost-efficient way reducing or zeroing their atmospheric carbon emissions. Aim of the present research is the investigation of using fuel cells for energy generation in hospitals with reference Venizelio hospital located in Crete, Greece. After surveying the existing literature an appraisal of energy consumption in hospitals is made taking into account published data from various hospitals worldwide. In the next section the energy consumption in various sectors in Venizelio hospital is stated and used for the calculation of the characteristics of a fuel cell system covering both the electricity and heating demand in the hospital. The same procedure is followed for the calculation of various parameters of a hybrid energy system consisted of a fuel cell and a solar-PV system covering both the electricity and heating demand in the hospital. The results are presented in tables included in the corresponding sections. The text ends with discussion of the findings and presentation of the conclusions drawn as well as a list of references used in the study.

\section{Literature Survey}

The literature review is divided in three sections including: a) various applications of renewable energies in hospitals, b) the use of fuel cells and $\mathrm{H}_{2}$ in the future carbon-free energy economy, and c) the use of fuel cells for energy generation in various buildings.

\subsection{Use of Renewable Energies in Hospitals}

Pina et al, 2018 have investigated the possibility of integrating solar-thermal systems, solar-PV systems and biomass burning technology in Brazilian hospitals. The authors stated that biomass is economically the most appropriate fuel for heat production. They also mentioned that according to local data solar-PV technology was better than solar thermal technology. A report regarding the energy use in hospitals has been published, 2015. The report mentioned that human and environmental health are connected. It is also stated that energy projects in hospitals regarding the improvement of their energy efficiency are more profitable that projects concerning the use of renewable energies. Vourdoubas, 2015 has investigated the creation of zero $\mathrm{CO}_{2}$ emission hospitals due to energy use. With reference a 
hospital located in Crete, Greece the author stated that the combined use of solar thermal energy, solar-PV energy, solid biomass and geothermal energy with heat pumps can cover all its energy needs zeroing its $\mathrm{CO}_{2}$ emissions. Vourdoubas, 2021 has studied the use of renewable energies for heat and cooling generation in hospitals. The author stated that current uses of renewable energies in hospitals are rather limited. He also mentioned that solar thermal energy, biomass and geothermal energy have been used so far providing heat and cooling in hospitals while their technologies are mature, reliable and cost-efficient. Bujak, 2010 has estimated the heat consumption for preparation of domestic hot water in public hospitals. The author stated that the annual heat consumption for hot water production in two large hospitals was at $2,500 \mathrm{KWh} / \mathrm{bed}$. The energy renovation in public buildings including hospitals has been studied in the EU funded project "Finerpol", 2017. In the hospital located in Ptolemaida, Northern Greece, heat was generated with solar collectors and using the local district heating system while space cooling was produced with a solar thermal absorption cooling unit. A report on sustainable hospitals has been published, 2017. The report stated various case studies regarding Australian hospitals concerning the use of renewable energy technologies for power, heat and cooling generation. Applications of solar electricity, solar heat, solar cooling, wind turbines, geothermal heat pumps and co-generation plants were mentioned in this report.

\subsection{Fuel Cells and Hydrogen}

A study regarding $\mathrm{H}_{2}$ has been published, 2003. The study stated that $\mathrm{H}_{2}$ and electricity together represent one of the most promising ways to realize sustainable energy while fuel cells provide the most efficient conversion device for converting $\mathrm{H}_{2}$ into electricity. It is also mentioned that both address all the major energy and environmental challenges. A report regarding fuel cells has been published, 2011. The report stated that the technology of stationary fuel cells is commercially available, reliable and suitable to a wide variety of applications. Decrease in fuel cells cost combined with federal and state support is making their use more affordable. A study concerning the technology, the regulations and the safety of using fuel cells in shipping has been published, 2017. Different fuel cell technologies are provided for possible applications in shipping. An overview of regulations and guidelines applicable for fuel cells' use in shipping are also stated. Wang et al, 2018 have reviewed the techno-economic challenges in fuel cell commercialization. The authors stated that although fuel cells are a novel energy technology their market penetration has not been achieved in significant scale. They also mentioned that although the current fuel cell manufacturing cost is still higher than the cost of internal combustion engines its operating costs are much lower. Weidner et al, 2019 have reviewed the global deployment of large capacity stationary fuel cells. The authors stated that more than $800 \mathrm{MW}$ of large stationary fuel cell systems, with rated power above $200 \mathrm{KW}$, have been installed worldwide before 2018. USA and South Korea have installed together almost $95 \%$ of the global capacity. They also mentioned that worldwide three fuel cell technologies dominate: molten carbonate fuel cells, solid oxide fuel cells and phosphoric acid fuel cells. 


\subsection{Use of Fuel Cells in Buildings}

The future of the fuel cell industry and the use of fuel cells in buildings have been analyzed in a workshop held in USA, 2002. In the workshop it was stated that fuel cells will be intimately integrated in buildings, part of a flexible portfolio of options for meeting energy needs and supporting the electric grid. Unnasch, 2002 has investigated the integration of a $\mathrm{H}_{2}$ energy station into a federal building. The author stated that $\mathrm{H}_{2}$ is useful as a vehicle fuel as well as for stationary co-generation of heat and power. Its use can be combined with the use of various renewable energy resources. Boulmrharj et al, 2020 have studied the fuel cell integration into buildings. The authors stated that fuel cells have high efficiency at $85-90 \%$ while they are capable for the production of both thermal energy and electricity using either natural gas or hydrogen. They also mentioned that their use implies lower GHG emissions while the cost of producing heat and electricity is lower compared with the cost of separate generation. Gurieff et al, 2020 have re-imagined hospitals as sustainable energy hubs. The authors stated that public hospitals are focal points for communities and they have the opportunity to pioneer in the transition to renewable energy. They also mentioned that hospitals can be transformed into networked clean energy hubs leading the transition to a low carbon economy. Felseghi et al, 2021 have studied the synergy between solar-PV panels and $\mathrm{H}_{2}$ fuel cells for a green power supply in a building. The authors stated that a hybrid solar- $\mathrm{H}_{2}$ energy system can provide the required energy in buildings improving their environmental sustainability. They mentioned that the abovementioned hybrid system can supply $100 \%$ of the required energy in buildings decreasing significantly their $\mathrm{CO}_{2}$ emissions. Solar-PV panels can provide $32 \%$ of the required annual electricity production while fuel cells can generate the remaining $68 \%$. A report regarding the use of hydrogen in buildings has been published, 2021. It was mentioned that several studies have already analyzed the possibilities of using $\mathrm{H}_{2}$ in buildings particularly in the Netherlands. It was also stated that $\mathrm{H}_{2}$ will play a very limited role in the built environment until 2030 while in new buildings the price of $\mathrm{H}_{2}$ should be decreased $(<3 € / \mathrm{kg})$ to be competitive to heat pumps.

\section{Energy Consumption in Hospitals}

Various studies concerning the energy consumption in hospitals worldwide have been made and reported. Hu et al, 2004 have estimated the energy consumption and the energy costs in large hospitals in Taiwan. The authors stated that air-conditioning is the major electricity end user accounting for more than $50 \%$ of the total energy use while the annual energy intensity is at $259.45 \mathrm{KWh} / \mathrm{m}^{2}$. Shen et al, 2019 have analyzed the building energy consumption in a hospital in hot summer and cold winter areas in China. The authors evaluated the annual energy consumption at $113.5 \mathrm{KWh} / \mathrm{m}^{2}$. They also mentioned that electricity had a share at $66 \%$ in the total energy mix. Ji et al, 2019 have evaluated the energy consumption performance in hospital buildings in China. The authors stated that electricity consumption had a share at $66 \%$ in the total energy consumption while air-conditioning was the highest electricity user. They also mentioned that the total energy consumption varies between $338.42 \mathrm{KWh} / \mathrm{m}^{2}$ to 382.65 $\mathrm{KWh} / \mathrm{m}^{2}$ depending on the number of beds. Bawaneh et al, 2019 have evaluated the energy consumption in health care facilities in USA. The authors stated that the annual energy consumption in USA hospitals ranges from $640.7 \mathrm{KWh} / \mathrm{m}^{2}$ (in very hot zones) to 781.1 
$\mathrm{KWh} / \mathrm{m}^{2}$ (in very cold zones) with an average value at $738.5 \mathrm{KWh} / \mathrm{m}^{2}$. Gonzalez Gonzalez et al, 2018 have evaluated the energy consumption in German hospitals. The authors during the period 2005-2015 implemented 90 energy audits in 23 public hospitals in Germany. They stated that their average annual energy consumption was estimated at $270 \mathrm{KWh} / \mathrm{m}^{2}$. Vourdoubas, 2018 has estimated the energy consumption and the carbon emissions in Venizelio hospital in Crete, Greece. The author mentioned that its total annual energy consumption was at $280.4 \mathrm{KWh} / \mathrm{m}^{2}$ while its annual $\mathrm{CO}_{2}$ emissions due to energy use were at $168 \mathrm{kgCO}_{2} / \mathrm{m}^{2}$. He also stated that the share of electricity in the energy mix at 187.03 $\mathrm{KWh} / \mathrm{m}^{2}$ was almost double than the share of heating oil at $93.38 \mathrm{KWh} / \mathrm{m}^{2}$. The majority of hospitals utilize grid electricity and heating oil or gas for heat generation. In many of them the share of electricity in the final energy mix is higher than the share of heating fuels. Table 1 presents the energy consumption in hospitals in various countries.

Table 1. Energy consumption in hospitals worldwide

\begin{tabular}{|l|l|l|l|}
\hline Author, year & Country & Annual energy consumption & Share of electricity in the energy mix \\
\hline [1] Hu et al, 2004 & Taiwan & $259.45 \mathrm{KWh} / \mathrm{m}^{2}$ & $>50 \%$ \\
\hline [2] Shen et al, 2019 & China & $113.5 \mathrm{KWh} / \mathrm{m}^{2}$ & $66 \%$ \\
\hline [3] Ji et al, 2019 & China & $338.42-382.65 \mathrm{KWh} / \mathrm{m}^{2}$ & \\
\hline [4] Bawaneh et al, 2019 & USA & $738.5 \mathrm{KWh} / \mathrm{m}^{2}$ & \\
\hline [5] Gonzalez et al, 2018 & Germany & $270 \mathrm{KWh} / \mathrm{m}^{2}$ & \\
\hline [6] Vourdoubas, 2018 & Greece & $280.4 \mathrm{KWh} / \mathrm{m}^{2}$ & $66.70 \%$ \\
\hline
\end{tabular}

Source: various authors

Energy consumption in hospitals varies significantly among different countries depending on the size, type of the hospital, local climate conditions, construction of the buildings etc. The use of renewable energies is rather limited so far while fossil fuels and electricity derived by them provide the required energy. In the next sections 4, 5 and 6 the values of electricity and heat consumption in Venizelio hospital are used in order to calculate the characteristics of a fuel cell system as well as a hybrid energy system consisted of a fuel cell and solar-PV panels covering the annual energy needs in the abovementioned hospital. Evaluation of various parameters of the two energy generation systems in the hospital are made using the design procedure for fuel cells and solar-PV systems. In section 7 discussion of the findings is made while in section 8 the conclusions drawn are presented.

\section{Energy Consumption and Fuels Used in Venizelio Hospital in Crete, Greece}

Venizelio hospital located in Heraklion, Crete, Greece has been used as a case study hospital in our study. It was established in 1967. Its covered area is $26172 \mathrm{~m}^{2}$, its capacity is 440 beds and its staff includes 1000 employees. The hospital covers all its energy needs with electricity and heating oil without using renewable energy sources so far. The annual electricity consumption, in 2015 , has been estimated at $4895 \mathrm{MWh}_{\mathrm{el}}$ while its annual heat consumption at $2444 \mathrm{MWh}_{\text {th }}$ (Vourdoubas, 2018). Its specific annual energy consumption has been estimated at $280.4 \mathrm{KWh} / \mathrm{m}^{2}$ the specific annual electricity consumption at 187.03 $\mathrm{KWh} / \mathrm{m}^{2}$ while the specific annual heating oil consumption at $93.38 \mathrm{KWh} / \mathrm{m}^{2}$. Most of its 
energy systems are old and inefficient. Their replacement with new energy systems is going to reduce its energy consumption and it would probably be profitable. The distribution of energy consumption in various sectors in the hospital has been assumed to follow the pattern presented in table 2.

Table 2. Distribution of energy consumption in Venizelio hospital

\begin{tabular}{|l|l|l|}
\hline Sector & Energy consumption (\%) & Annual energy consumption (MWh) \\
\hline Space heating & 34 & 2495 \\
\hline Hot water production & 13 & 954 \\
\hline Space cooling & 18 & 1321 \\
\hline Lighting & 14 & 1028 \\
\hline Other electrical uses & 21 & 1541 \\
\hline Total & 100 & 7339 \\
\hline
\end{tabular}

Source: Vourdoubas, 2018

Thermal uses in the hospital including space heating and hot water production have a share at $47 \%$ in the total energy mix while space cooling, lighting and electricity consumption in various machinery and equipment have a share at $53 \%$.

\section{Use of a Fuel Cell Covering both the Electricity and Heating Needs in Venizelio Hospital}

Fuel cells co-generating heat and power can cover the energy requirements in Venizelio hospital. The sizing of the fuel cell as well as the hybrid energy system presented below are based on the annual energy balance in the hospital. The following assumptions have been made:

1. The annual electricity consumption is at $4895 \mathrm{MWh}_{\mathrm{el}}$,

2. The annual heat consumption is at $2444 \mathrm{MWh}_{\text {th }}$,

3. The efficiency of the fuel cell is $40 \%$ in electricity generation and $40 \%$ in heat production while it operates 8760 hours annually, and

4. The energy content of $\mathrm{H}_{2}$ is $33.30 \mathrm{KWh} / \mathrm{kgH}_{2}$.

The size of the required fuel cell is estimated at $1397 \mathrm{KW}$. It will generate annually 4895 $\mathrm{MWh}_{\mathrm{el}}$ and $4895 \mathrm{MWh}_{\mathrm{th}}$. Since the annual heat requirements in the hospital are only 2444 $\mathrm{MWh}_{\text {th }}$ the excess heat produced at $2451 \mathrm{MWh}_{\text {th }}$ should be utilized in other activities probably located in nearby areas. The annual quantity of the necessary $\mathrm{H}_{2}$ fuelling the fuel cell is estimated at 367.5 tons. Taking into account that the unit cost of a fuel cell is at 3000 $€ / \mathrm{KW}$ the cost of the fuel cell covering the electricity and heating needs, producing additionally excess heat, in Venizelio hospital is at $4191000 €$. The characteristics of the fuel cell are presented in table 3. 


\section{Macrothink}

Environmental Management and Sustainable Development

ISSN 2164-7682

2022, Vol. 11, No. 1

Table 3. Characteristics of a fuel cell covering both the electricity and heating needs in Venizelio hospital

\begin{tabular}{|l|l|}
\hline Annual electricity requirements & $4895 \mathrm{MWh}_{\mathrm{el}}$ \\
\hline Annual heat requirements & $2444 \mathrm{MWh}_{\mathrm{th}}$ \\
\hline Size of the fuel cell & $1397 \mathrm{KW}$ \\
\hline Efficiency of the fuel cell & $40 \%$ in electricity generation and $40 \%$ for heat production \\
\hline Annual electricity generation by the fuel cell & $4895 \mathrm{MWh}_{\mathrm{el}}$ \\
\hline Annual heat production by the fuel cell & $4895 \mathrm{MWh}_{\mathrm{th}}$ \\
\hline $\begin{array}{l}\text { Annual excess heat production that should be } \\
\text { utilized outside the hospital }\end{array}$ & $2451 \mathrm{MWh}_{\mathrm{th}}$ \\
\hline Cost of the fuel cell & $4191000 €$ \\
\hline Necessary $\mathrm{H}_{2}$ in the fuel cell & 367.5 tons/year \\
\hline Annual $\mathrm{CO}_{2}$ savings due to the use of the fuel cell & $4396896 \mathrm{kgCO}_{2}$ \\
\hline Energy investment per $\mathrm{CO}_{2}$ savings & $0.95 € / \mathrm{kgCO}_{2}$ \\
\hline
\end{tabular}

Source: Own estimations

\section{Use of a Hybrid Energy System Including a Fuel Cell and a Solar-PV System Covering both the Electricity and Heating Needs in Venizelio Hospital}

A hybrid energy system consisted of a fuel cell and a solar-PV system can also cover the energy requirements in Venizelio hospital in Crete, Greece. For sizing the hybrid energy system the following assumptions have been made:

1. The annual electricity consumption is at $4895 \mathrm{MWh}_{\mathrm{el}}$,

2. The annual heat consumption is at $2444 \mathrm{MWh}_{\text {th }}$,

3. The efficiency of the fuel cell is $40 \%$ in electricity generation and $40 \%$ in heat production while it operates 8760 hours annually,

4. The solar-PV system generates annually in Crete $1500 \mathrm{KWh}_{\mathrm{e}} / \mathrm{KW}_{\mathrm{p}}$,

5. The fuel cell will cover all the heat requirements in the hospital and part of its electricity requirements while the solar-PV system will cover the remaining electricity requirements.

The size of the fuel cell system is estimated at $697.5 \mathrm{KW}$. It will generate annually 2444 $\mathrm{KWh}_{\text {th }}$ and $2444 \mathrm{KWh}_{\mathrm{el}}$. The remaining electricity required annually in the hospital at 2451 $\mathrm{MW}_{\mathrm{el}}$ will be generated by the solar-PV system. The size of the solar-PV system is estimated at $1634 \mathrm{KW}_{\mathrm{p}}$. The annual quantity of the necessary $\mathrm{H}_{2}$ fuelling the fuel cell is estimated at 183.5 tons. Taking into account the unit cost of a fuel cell at $3000 € / \mathrm{KW}$ and of a solar-PV system at $1000 € / \mathrm{KW}_{\mathrm{p}}$ the cost of the fuel cell is at $2092500 €$ while of the solar-PV system at $1634000 €$. The total cost of the hybrid energy system at $3726500 €$ is lower than the cost of the fuel cell estimated in the previous case at $4191000 €$ while there is not excess heat generated by the hybrid energy system in the hospital. The characteristics of the fuel cell and the solar-PV system are presented in table 4. 
Table 4. Characteristics of a hybrid energy system consisted of a fuel cell and a solar-PV system covering both the electricity and heating needs in Venizelio hospital

\begin{tabular}{|l|l|}
\hline Annual electricity requirements & $4895 \mathrm{MWh}_{\mathrm{el}}$ \\
\hline Annual heat requirements & $2444 \mathrm{MWh}_{\mathrm{th}}$ \\
\hline Size of the fuel cell & $697.5 \mathrm{KW}$ \\
\hline Efficiency of the fuel cell & $\begin{array}{l}40 \% \text { in electricity generation and } \\
40 \% \text { for heat production }\end{array}$ \\
\hline Annual electricity generation by the fuel cell & $2444 \mathrm{MWh}_{\mathrm{el}}$ \\
\hline Percentage of electricity generation by the fuel cell & $49.93 \%$ \\
\hline Annual heat production by the fuel cell & $2444 \mathrm{MWh}_{\mathrm{th}}$ \\
\hline Size of the solar-PV system & $1629 \mathrm{KW}_{\mathrm{p}}$ \\
\hline Annual electricity generation by the solar-PV system & $2451 \mathrm{MWh}_{\mathrm{th}}$ \\
\hline Percentage of electricity generation by the solar-PV system & $50.07 \%$ \\
\hline Total electricity generation by the hybrid energy system & $4895 \mathrm{MWh}_{\mathrm{el}}$ \\
\hline Cost of the fuel cell & $2092500 €$ \\
\hline Cost of the solar-PV system & $1634000 €$ \\
\hline Total cost of the hybrid energy system & $3726500 €$ \\
\hline Necessary $\mathrm{H}_{2}$ in the fuel cell & 183.5 tons/year \\
\hline Annual $\mathrm{CO}_{2}$ savings due to the use of the hybrid energy system & $4396896 \mathrm{kgCO}_{2}$ \\
\hline Energy investment per $\mathrm{CO}_{2}$ savings & $0.85 € / \mathrm{kgCO}_{2}$ \\
\hline
\end{tabular}

Source: Own estimations

\section{Discussion}

Our research indicates that fuel cells can cover both the heat and electricity needs in Venizelio hospital located in Crete, Greece. Hybrid energy systems consisted of fuel cells and solar-PVs can also provide the required heat and electricity in the hospital. Old buildings, like the buildings in Venizelio hospital, have poor energy performance requiring energy renovation and reducing their energy consumption. It is expected that approximately $20 \%$ of energy saving in the hospital can be achieved with the implementation of various energy saving measures particularly in the building envelope. This will reduce significantly the size of the necessary sustainable energy systems for zeroing its net carbon emissions. Specific energy consumption in Venizelio hospital is at the same level as reported in other countries except in USA where the energy consumption is higher. When "green electrolytic $\mathrm{H}_{2}$ " is used in fuel cells the net carbon emissions due to energy use are zero resulting in a green sustainable hospital. The economics of energy generation by the fuel cell are favored when the price of $\mathrm{H}_{2}$ is low while electricity generation by solar-PVs in currently profitable in Crete. The installation cost of fuel cells is not high while it is subsidized by the government in many countries. Existing studies indicate that fuel cells can provide both heat and electricity in buildings covering their energy requirements while their total energy efficiency is very high exceeding $80 \%$. It has been also reported that fuel cells combined with solar-PV systems can be used for heat and power generation in buildings while hospitals are focal points in various communities leading the transition towards renewable energy systems. Promotion of $\mathrm{H}_{2}$ economy in the coming decades will accelerate the use of fuel cells, as well as other benign energy systems, in various buildings including hospitals partly or totally eliminating the use 
of fossil fuels and carbon emissions in them. Future research should be focused in an energy cost analysis comparing the operating cost of the existing conventional energy systems using fossil fuels in Venizelio hospital with the operating cost of the sustainable energy systems, including fuel cells and solar-PVs, presented in the current study.

\section{Conclusions}

The use of sustainable energy systems including fuel cells and solar-PVs in Venizelio hospital located in Crete, Greece has been studied. These systems can cover all its electricity and heating requirements replacing fossil fuels and zeroing its carbon emissions due to energy use. Our results indicated that use of a fuel cell at $1397 \mathrm{KW}$ can cover all the energy needs in the hospital generating $4895 \mathrm{MWh}_{\mathrm{el}}$ electricity and $4895 \mathrm{MWh}_{\mathrm{th}}$ of heat energy. The heat produced by the fuel cell is higher than the required in the hospital and the excess heat should be utilized in other activities nearby the hospital. The capital cost of the fuel cell has been calculated at $4191000 €$ while the required $\mathrm{H}_{2}$ at 367.5 tons/year. A hybrid energy system consisted of a fuel cell and a solar-PV system can also cover the power and heating requirements in the hospital. The size of the fuel cell has been evaluated at $697.5 \mathrm{KW}$ while of the solar-PV system at $1629 \mathrm{KW}_{\mathrm{p}}$. The annual electricity generation by the fuel cell was estimated at $2444 \mathrm{MWh}_{\mathrm{el}}$ while the heat production at $2444 \mathrm{KWh}_{\mathrm{th}}$. The annual electricity generation by the solar-PV system was at $2451 \mathrm{MWh}_{\mathrm{el}}$. The cost of the fuel cell has been estimated at $2092500 €$ while of the solar-PV system at $1634000 €$. The total capital cost of the hybrid system at $3726000 €$ was lower than the capital cost of the fuel cell alone at 4191 $000 €$. Assuming that the fuel cell will utilize "green hydrolytic $\mathrm{H}_{2}$ " at an affordable cost the use of the abovementioned novel energy systems could zero the annual carbon emissions in Venizelio hospital due to energy use in a cost-efficient way. The capital investment for achieving a "zero carbon Venizelio hospital" is, in the case of the fuel cell alone, at $0.95 €$ per $\mathrm{kg}$ of $\mathrm{CO}_{2}$ savings while in the case of the hybrid energy system at $0.85 €$ per $\mathrm{kg}$ of $\mathrm{CO}_{2}$ savings. Our results indicated that the achievement of the EU target for zeroing net carbon emissions by 2050 is technically and economically feasible in Venizelio hospital.

\section{References}

Bawaneh, K., Chazi Nezami, F., Rasheduzzaman, Md., \& Deken, B. (2019). Energy consumption analysis and characterization of healthcare facilities in the United States. Energies, 12, 3775. https://doi.org/10.3390/en12193775

Boulmrharj, S., Khaidar, M., Siniti, M., Bankhouya, M., \& Zine-dine, K. (2020). Towards performance assessment of fuel cell integration into buildings. Energy Reports, 6, 288-293. https://doi.org/10.1016/j.egyr.2019.08.058

Bujak, J. (2010). Heat consumption for preparing domestic hot water in hospitals. Energy and Buildings, 42, 1047-1055. https://doi.org/10.1016/j.enbuild.2010.01.017

Burger, B., \& Newman, P. (2017). Hospitals and Sustainability, Curtin University of Technology, Australia. [Online] Available:

https://sustainability.curtin.edu.au/wp-content/uploads/sites/31/2017/06/hospitals-sustainabilit y.pdf 


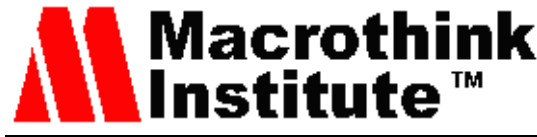

Energy information and resources for hospitals in New Hampshire. (2015). [Online] Available:https://archive.epa.gov/region1/healthcare/web/pdf/energy_information_and_resou rces_for_hospitals_in_new_hampshire_-_final_1.pdf

Felseghi, R-A., Aschilean, I., Cobizzan, N., Bolboaca, A. M., \& Raboaca, M. S. (2021). Optimal synergy between photovoltaic panels and hydrogen fuel cells for green power supply of a green building - A case study. Sustainability, 13, 6304.

https://doi.org/10.3390/su13116304

Finerpol, 5th Interregional Event, Dossier Kozani, Greece. (2017). [Online] Available: https://www.interregeurope.eu/fileadmin/user_upload/tx_tevprojects/library/DOSSIER-5thIE _2017_05_01.pdf

Fuel cell for buildings and stationary applications - Roadmap workshop, Maryland, USA. (2002). [Online] Available:

https://www1.eere.energy.gov/hydrogenandfuelcells/pdfs/stationary_fc_proceedings.pdf

Fuel cells: Briefing papers for state policy makers, Clean Energy States Alliance. (2011). [Online] Available: https://www.cesa.org/wp-content/uploads/CESA-Fuel-Cells-Brifing-Pape rs-for-State-Policymakers-Aug2.pdf

Gonzalez Gonzalez, A., Garcia-Sanz-Calcedo, J., \& Rodriguez Salgado, D. (2018). Evaluation of energy consumption in German hospitals: Benchmarking in the public sector. Energies, 11, 2279. https://doi.org/10.3390/en11092279

Gurieff, N., Green, D., Koskinen, I., Lipson, M., Baldry, M., Maddocks, A., ... Doroodchi, E. (2020). Healthy power: Reimagining hospitals as sustainable energy hubs. Sustainability, 12, 8554. https://doi.org/10.3390/su12208554

Hydrogen energy and fuel cells, A vision of our future, EU. (2003). [Online] Available: https://www.fch.europa.eu/sites/default/files/documents/hlg_vision_report_en.pdf

Hu, S. C., Chen, J. D., \& Chuah, Y. K. (2004). Energy cost and consumption in a large acute hospital. International Journal on Architectural Science, 5(1), 11-19. [Online] Available: https://www.bse.polyu.edu.hk/researchCentre/Fire_Engineering/summary_of_output/journal/I JAS/V5/p.11-19.pdf

Ji, R., \& Qu, Sh. (2019). Investigation and evaluation of energy consumption performance for hospital buildings in China. Sustainability, 11, 1724. https://doi.org/10.3390/su11061724

Pina, E. A., Lozano, M. A., \& Serra, L. M. (2018). Opportunities for the integration of solar thermal heat, photovoltaics and biomass in a Brazilian hospital, GITSE-I3A. https://doi.org/10.18086/eurosun2018.05.03

Ronge, J., \& Francois, I. (2021). Use of hydrogen in buildings, BatHybuild Study. [Online] Available: https://www.waterstofnet.eu/_asset/_public/BatHyBuild/Hydrogen-use-in-builings -BatHyBuild-29042021.pdf

Shen, C., Zhao, K., Ge, J., \& Zhou, Q. (2019). Analysis of building energy consumption in a 


\section{Macrothink}

Environmental Management and Sustainable Development

ISSN 2164-7682 2022, Vol. 11, No. 1

hospital in the hot summer and cold winter area. Energy Procedia, 158, 3735-3740. https://doi.org/10.1016/j.egypro.2019.01.883

Study on the use of fuel cells in shipping, European Maritime Safety Agency. (2017).

Unnasch, S. (2002). Technical Analysis: Integrating a hydrogen energy station into a federal building, Proceedings of the 2002 US DOE Hydrogen Program Review, NREL/CP-610-32405. [Online] Available: https://www.nrel.gov/docs/fy02osti/32405b6.pdf

Vourdoubas, J. (2015). Creation of zero $\mathrm{CO}_{2}$ emissions hospitals due to energy use. A case study in Crete-Greece. Journal of Engineering and Architecture, 3(2), 79-86.

https://doi.org/10.15640/jea.v3n2a9

Vourdoubas, J. (2018). Energy consumption and carbon emissions in Venizelio hospital in Crete, Greece: can it be carbon neutral? Journal of Engineering and Architecture, 6(1), 19-27. https://doi.org/10.11114/set.v6i1.4013

Vourdoubas, J. (2021). Use of renewable energy sources for heat and cooling generation in hospitals. American Scientific Research Journal for Engineering, Technology and Sciences, 79(1), 98-112. https://doi.org/10.24018/ejgeo.2020.1.6.88

Wang, J., Wang, H., \& Fan, Y. (2018). Techno-economic challenges of fuel cell commercialization. Engineering, 4, 352-360. https://doi.org/10.1016/j.eng.2018.05.007

Weidner, E., Ortiz Cebolla, R., \& Davies, J. (2019). Global deployment of large capacity stationary fuel cells. JRC Technical Report.

\section{Copyright Disclaimer}

Copyright for this article is retained by the author(s), with first publication rights granted to the journal.

This is an open-access article distributed under the terms and conditions of the Creative Commons Attribution license (http://creativecommons.org/licenses/by/4.0/). 